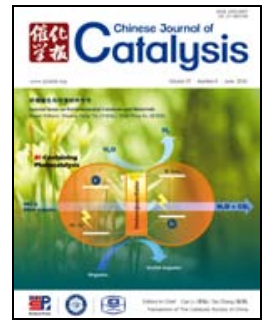

Article (Special Issue on Environmental Catalysis and Materials)

\title{
Fabrication and characterization of tungsten-containing mesoporous silica for heterogeneous oxidative desulfurization
}

\author{
Ming Zhang a, Wenshuai Zhu ${ }^{\mathrm{b}, *}$, Hongping Li ${ }^{\mathrm{b}}$, Suhang Xun ${ }^{\mathrm{b}}$, Meng Li ${ }^{\mathrm{b}}$, Yanan Li ${ }^{\mathrm{b}}$, Yanchen Wei ${ }^{\mathrm{b}}$, \\ Huaming $\mathrm{Li}^{\mathrm{a}, \mathrm{b}, \#}$ \\ a Institute for Energy Research, Jiangsu University, Zhenjiang 212013, Jiangsu, China \\ ${ }^{\mathrm{b}}$ School of Chemistry and Chemical Engineering, Jiangsu University, Zhenjiang 212013, Jiangsu, China
}

\section{A R T I C L E I N F O}

\section{Article history:}

Received 29 January 2016

Accepted 7 April 2016

Published 5 June 2016

\section{Keywords:}

Heterogeneous oxidative

desulfurization

Tungsten species

Mesoporous silica

One-pot synthesis

Organosulfur

\begin{abstract}
A B S T R A C T
A series of functional, tungsten-containing mesoporous silica materials $\left(\mathrm{W}-\mathrm{SiO}_{2}\right)$ have been fabricated directly from an ionic liquid that contained imidazole and polyoxometalate, which acted as mesoporous template and metal source respectively. These materials were then characterized through X-ray diffraction (XRD), transmission electron microscopy (TEM), Raman spectroscopy, Fourier transform infrared spectra (FTIR), diffuse reflectance spectra (DRS), and $\mathrm{N}_{2}$ adsorption-desorption, which were found to contain tungsten species that were effectively dispersed throughout the structure. The as-prepared materials $\mathrm{W}-\mathrm{SiO}_{2}$ were also found to possess a mesoporous structure. The pore diameters of the respective sample $\mathrm{W}-\mathrm{SiO}_{2}-20$ determined from the TEM images ranged from 2 to $4 \mathrm{~nm}$, which was close to the average pore size determined from the nitrogen desorption isotherm $(2.9 \mathrm{~nm})$. The materials were evaluated as catalysts for the heterogeneous oxidative desulfurization of dibenzothiophene (DBT), which is able to achieve deep desulfurization within 40 min under the optimal conditions (Catalyst $\left(\mathrm{W}-\mathrm{SiO}_{2}-20\right)=0.01 \mathrm{~g}$, temperature $=60{ }^{\circ} \mathrm{C}$, oxidant $\left(\mathrm{H}_{2} \mathrm{O}_{2}\right)=20 \mu \mathrm{L}$ ). For the removal of different organic sulfur compounds within oil, the ability of the catalyst $\left(\mathrm{W}-\mathrm{SiO}_{2}-20\right)$ under the same conditions to remove sulfur compounds decreased in the order: 4,6-dimethyldibenzothiophene $>$ Dibenzothiophene $>$ Benzothiophene $>$ 1-dodecanethiol. Additionally, they did not require organic solvents as an extractant in the heterogeneous oxidative desulfurization process. After seven separate catalytic cycles, the desulfurization efficiency was still as high as $90.3 \%$. From the gas chromatography-mass spectrometer analysis, DBT was entirely oxidized to its corresponding sulfone $\mathrm{DBTO}_{2}$ after reaction. A mechanism for the heterogeneous desulfurization reaction was proposed.
\end{abstract}

(C) 2016, Dalian Institute of Chemical Physics, Chinese Academy of Sciences. Published by Elsevier B.V. All rights reserved.

\section{Introduction}

As the worldwide demand for fuel continues to increase rapidly, the industrial desulfurization of diesel fuel faces increasing technological challenges to comply with environmental concerns and legal requirements [1,2].
Hydrodesulfurization (HDS) is a mature technology and efficiently removes aliphatic and acyclic sulfur compounds (e.g. thiols, sulfides, and disulfides) [3-5] but not thiophene sulfides, such as dibenzothiophene and its derivatives [6-8]. Additionally, further improvements to the HDS process for deep desulfurization are limited to increasingly harsh operating condi-

\footnotetext{
* Corresponding author. Tel: +86-511-88791800; Fax: +86-511-88791708; E-mail: zhuws@ujs.edu.cn

\# Corresponding author. Tel: +86-511-88791800; Fax: +86-511-88791708; E-mail: lhm@ujs.edu.cn

This work was supported by the National Nature Science Foundation of China $(21276117,21376111,21406092)$.

DOI: 10.1016/S1872-2067(15)61103-2 | http://www.sciencedirect.com/science/journal/18722067 | Chin. J. Catal., Vol. 37, No. 6, June 2016
} 
tions with high associated costs $[9,10]$. Hence, it is critical to develop supplementary strategies for deep desulfurization, including extraction [11-14], adsorption [15,16], oxidation [17-22], and biodesulfurization [23]. Oxidative desulfurization (ODS) can remove aromatic organosulfur compounds under mild conditions. As such, it is considered as a promising technique for deep desulfurization.

Ionic liquids (ILs) are organic salts with low melting points and vapor pressures, and have attracted wide attention owing to their unique physicochemical properties, including negligible volatility, low toxicity, excellent thermal stability, good solubility characteristics, and the variety of available structures [24]. Task-specific IL anions that are tethered to functional groups (e.g. polyoxometalates) show great potential for the modification and control of different chemical and physical functions in a material [25-27]. Polyoxometalates (POMs) are a vast class of well-defined, early transition metal oxyanion clusters that exhibit distinctive physicochemical properties, including adjustability of composition, size, shape, acid-base properties, and redox potential [28-32]. As such, POMs are extensively used as green catalysts, particularly in oxidation reactions [33,34]. A number of studies have demonstrated that POM-based ILs exhibited efficient catalytic ODS [35-37]. However, the widespread use of these materials for homogeneous desulfurization in an industrial setting has been hindered because of their intrinsic liquid nature and high viscosity, which leads to difficulties in separation and recovery, recyclability, cost, and the large amounts of ILs that are required [38].

To overcome some of these problems, considerable efforts have been made to introduce active POM-based species into heterogeneous desulfurization systems, where materials such as zeolites, porous carbon, clays, siliceous materials, and metal-organic frameworks were employed as a support [39-44]. Among these supports, mesoporous silica possesses a number of desirable properties, including a stable mesoporous structure, a large surface area and pore volume, well-ordered pore structure, and narrow pore-size distributions. Moreover, silica has no inherent catalytic property and can be used as a support that can be functionalized by framework substitution or post-synthesis surface modification. As such, POM-based IL-supported mesoporous silica has been fabricated for ODS, but required relatively excessive oxidants. Additionally, the requirement for organic solvents (e.g. acetonitrile and dimethylformamide) may limit future applications of these materials $[45,46]$.

In this work, active tungsten species were introduced directly into mesoporous silica from a POM-based IL ( $\left.\left[\mathrm{C}_{16} \mathrm{mim}\right]_{3} \mathrm{PW}_{12} \mathrm{O}_{40}\right)$, where the imidazole cation and polyoxometalate anion acted as template and metal source, respectively. The hybrid materials $\left(\mathrm{W}-\mathrm{SiO}_{2}\right)$ were highly effective on removing organosulfur compounds under mild conditions and were separated easily for recycling. Additionally, organic solvents were not required for the heterogeneous desulfurization. All samples were characterized using X-ray diffraction, Transmission electron microscopy, Raman spectroscopy, Fourier transform infrared spectra, Diffuse reflectance spectra, and Brunauer-Emmett-Teller analysis.

\section{Experimental}

\subsection{Materials}

$\mathrm{H}_{2} \mathrm{O}_{2}$ (aqueous solution, 30 wt $\%$ ), $\mathrm{H}_{3} \mathrm{PW}_{12} \mathrm{O}_{40} \cdot 14 \mathrm{H}_{2} \mathrm{O}$ (AR grade), $\mathrm{WO}_{3}$ (AR grade), $n$-octane (AR grade), $\mathrm{NH}_{3} \cdot \mathrm{H}_{2} \mathrm{O}$ (aqueous solution, $25 \mathrm{wt} \%$ ), acetonitrile (AR grade), tetraethyl orthosilicate (TEOS, AR grade) and tetradecane (AR grade) were purchased from Sinopharm Chemical Reagent Co., Ltd. Benzothiophene (BT, 99\%), dibenzothiophene (DBT, 98\%) 1-dodecanethiol (DT, 99\%), and 4,6-dimethyldibenzothiophene (4,6-DMDBT,99\%) were purchased from Sigma-Aldrich. [ $\left.\mathrm{C}_{16 \mathrm{mim}}\right] \mathrm{Br}$ was purchased from Shanghai Chengjie Chemical Co., Ltd. All the materials are used without further purification.

\subsection{Sample preparation}

The POM-based IL $\left[\mathrm{C}_{16} \mathrm{mim}\right]_{3} \mathrm{PW}_{12} \mathrm{O}_{40}$ was prepared according to a literature procedure [47]. The mesoporous hybrid material $\left(\mathrm{W}-\mathrm{SiO}_{2}\right)$ was prepared using a one-pot method from an initial gel that consisted of TEOS: $\left[\mathrm{C}_{16} \mathrm{mim}\right]_{3} \mathrm{PW}_{12} \mathrm{O}_{40}: \mathrm{H}_{2} \mathrm{O}$ : $\mathrm{NH}_{3} \cdot \mathrm{H}_{2} \mathrm{O}=1: x: 160: 1.5(x=0.002,0.004,0.008)$. In a typical synthesis, $\left[\mathrm{C}_{16} \mathrm{mim}\right]_{3} \mathrm{PW}_{12} \mathrm{O}_{40}(0.14 \mathrm{~g})$ was added into acetonitrile ( $4 \mathrm{~mL}$ ) with constant stirring. Subsequently, TEOS (2 mL) and $\mathrm{NH}_{3} \cdot \mathrm{H}_{2} \mathrm{O}(0.52 \mathrm{~mL})$ were added into the mixture and stirred for $3 \mathrm{~h}$. The resulting gel was filtered, washed with water $(200 \mathrm{~mL})$, dried overnight at $120^{\circ} \mathrm{C}$, and then calcined at $550{ }^{\circ} \mathrm{C}$ with a heating rate of $5{ }^{\circ} \mathrm{C} / \mathrm{min}$ for $6 \mathrm{~h}$. The samples were named based on the $\mathrm{Si} / \mathrm{W}$ molar ratio used in the gel $\left(\mathrm{W}-\mathrm{SiO}_{2}-y\right.$, where $y=\mathrm{Si} / \mathrm{W}=10,20$ and 40 ).

\subsection{Characterization and methods}

The samples were ground into a fine powder for characterization. Fourier transform infrared (FT-IR) spectra were recorded with a Nicolet Nexus 470 FT-IR instrument using $\mathrm{KBr}$ pellets. Raman spectroscopy was recorded at ambient temperature using a DXR Raman microscope with an excitation wavelength of $532 \mathrm{~nm}$ from a laser source. Diffuse reflectance spectra (DRS) were measured between 200 and $800 \mathrm{~nm}$ with $\mathrm{BaSO}_{4}$ used as the reflectance standard using a UV-visible spectrometer (UV-2450, Shimadzu). The surface area of the samples was calculated using the Brunauer-Emmett-Teller (BET) method, while the pore-size distribution was obtained from the adsorption branches of the isotherms using the Barrett-JoynerHalenda (BJH) method. Transmission electron microscopy (TEM) was recorded using a JEOL-JEM-2010 (JEOL, Japan) operated at $200 \mathrm{kV}$. The crystalline phases within the samples were analyzed using X-ray diffraction (XRD) spectroscopy with a Bruker D8 diffractometer with $\mathrm{Cu} K_{\alpha}$ radiation $(\lambda=0.154 \mathrm{~nm})$.

\subsection{Catalytic activity test}

A model oil sample was prepared by dissolving DBT, BT, DT and 4,6-DMDBT in $n$-octane with a corresponding sulfur content of 500, 250, 250 and 250 ppm, respectively. Desulfurization was performed in a flask equipped with a magnetic stirrer 
and condenser. In a typical run, a water bath was initially heated to $60{ }^{\circ} \mathrm{C}$ then allowed to stabilize. W-SiO $2(0.01 \mathrm{~g})$ and $\mathrm{H}_{2} \mathrm{O}_{2}(20 \mu \mathrm{L})$ were added to the reactor and then the oil $(5 \mathrm{~mL})$ was injected.

\subsection{Analysis method of products}

The sulfur contents in the oil after the desulfurization test were analyzed using gas chromatography-flame ionization detector (GC-FID) with tetradecane as the internal standard (Agilent 7890A; HP-5, $30 \mathrm{~m} \times 0.32 \mathrm{~mm} \times 0.25 \mu \mathrm{m}$; FID: Agilent) The conversion of the sulfur compounds in the oil was used to calculate the removal of sulfur compounds.

The oxidized sulfur compounds were characterized using gas chromatography-mass spectrometer (GC-MS, Agilent 7890/ 5975C-GC/MSD; HP-5 MS column, $30 \mathrm{~m} \times 250 \mu \mathrm{m} \times 0.25 \mu \mathrm{m}$; temperature program: $100{ }^{\circ} \mathrm{C} \rightarrow$ temperature rising $15^{\circ} \mathrm{C} / \mathrm{min}$ $\rightarrow 200{ }^{\circ} \mathrm{C}$ for $10 \mathrm{~min}$ ).

\section{Results and discussion}

\subsection{Characterization of the catalysts}

FT-IR spectra of $\mathrm{W}-\mathrm{SiO}_{2}-y, \mathrm{WO}_{3}$ and $\left[\mathrm{C}_{16} \mathrm{mim}_{3} \mathrm{PW}_{12} \mathrm{O}_{40}\right.$ are shown in Fig. 1. The spectrum of bulk $\mathrm{WO}_{3}$ (Fig. 1(1)) exhibited a strong and broad peak at approximately $820 \mathrm{~cm}^{-1}$ that was caused by the stretching vibrations of $\mathrm{W}-\mathrm{O}-\mathrm{W}$. In addition to the $\mathrm{C}-\mathrm{H}$ stretching vibrations of the alkyl chain (2950 to 2850 $\mathrm{cm}^{-1}$ ), [ $\left.\mathrm{C}_{16} \mathrm{mim}\right]_{3} \mathrm{PW}_{12} \mathrm{O}_{40}$ (Fig. 1(2)) exhibited four bands that were characteristic of Keggin units $\left(V_{\text {as }}\left(\mathrm{P}-\mathrm{O}_{\mathrm{a}}\right)=1080 \mathrm{~cm}^{-1}\right.$, $\nu_{\mathrm{as}}\left(\mathrm{W}=\mathrm{O}_{\mathrm{t}}\right)=978 \mathrm{~cm}^{-1}, \quad \nu_{\mathrm{as}}\left(\mathrm{W}-\mathrm{O}_{\mathrm{c}}-\mathrm{W}\right)=898 \mathrm{~cm}^{-1}$ and $\nu_{\text {as }}\left(\mathrm{W}-\mathrm{O}_{\mathrm{e}}-\mathrm{W}\right)=808 \mathrm{~cm}^{-1}$ ). The $\mathrm{W}-\mathrm{SiO}_{2}-y$ materials (Fig. 1(3)-(5)) exhibited a broad peak near $3500 \mathrm{~cm}^{-1}$ that was attributed to surface silanols and adsorbed water molecules [48]. The three peaks located at 1086, 812, and $460 \mathrm{~cm}^{-1}$ were caused by asymmetric $v_{\text {asym }}(\mathrm{Si}-\mathrm{O}-\mathrm{Si})$, symmetric $v_{\text {sym }}(\mathrm{Si}-\mathrm{O}-\mathrm{Si})$ and bending modes of the $\mathrm{SiO}_{4}$ tetrahedra vibrations within the silica, respectively $[49,50]$. The band near $954 \mathrm{~cm}^{-1}$ in the $\mathrm{W}-\mathrm{SiO}_{2}-y$ materials was characteristic of $\mathrm{Si}-\mathrm{O}-\mathrm{W}$ bonds, which indicated that tungsten species were incorporated into the framework of the mesoporous silica matrix [51].

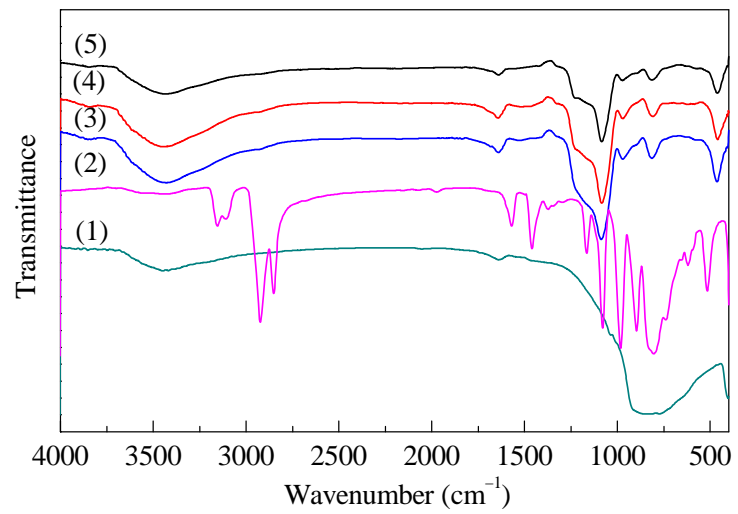

Fig. 1. FT-IR spectra of (1) $\mathrm{WO}_{3},(2)\left[\mathrm{C}_{16} \mathrm{mim}\right]_{3} \mathrm{PW}_{12} \mathrm{O}_{40}$, (3) $\mathrm{W}-\mathrm{SiO}_{2}-10$, (4) $\mathrm{W}-\mathrm{SiO}_{2}-20$, and (5) $\mathrm{W}-\mathrm{SiO}_{2}-40$.

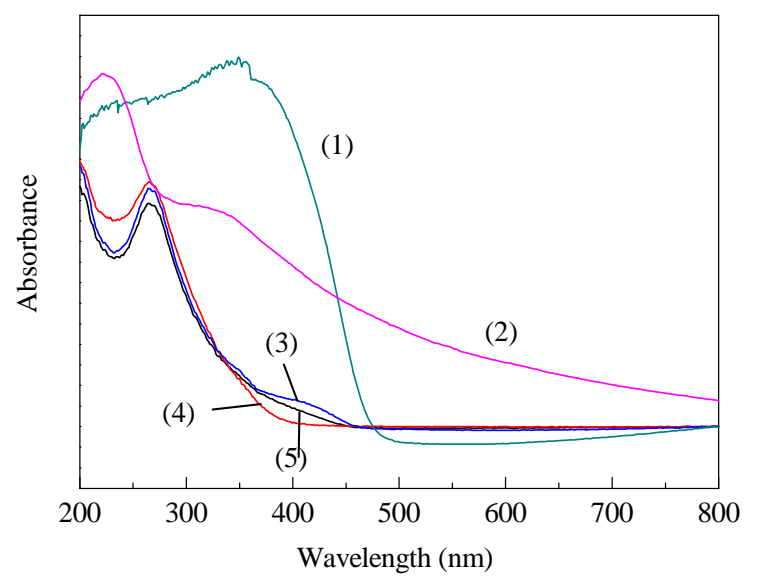

Fig. 2. UV-vis diffuse reflectance spectra of (1) $\mathrm{WO}_{3}, \quad$ (2) $\left[\mathrm{C}_{16} \mathrm{mim}_{3} \mathrm{PW}_{12} \mathrm{O}_{40},(3) \mathrm{W}-\mathrm{SiO}_{2}-10,(4) \mathrm{W}-\mathrm{SiO}_{2}-20\right.$, and (5) W-SiO $2-40$.

The electronic behavior of the materials was examined using UV-vis DRS, as shown in Fig. 2. The spectrum of $\left[\mathrm{C}_{16} \mathrm{mim}\right]_{3} \mathrm{PW}_{12} \mathrm{O}_{40}$ exhibited an absorption band at approximately $212 \mathrm{~nm}$ that was assigned to an O-P transition, while the absorption peak located at $260 \mathrm{~nm}$ was ascribed to a charge transfer transition within the Keggin units. Bulk $\mathrm{WO}_{3}$ exhibited a strong absorption near $430 \mathrm{~nm}$ that was assigned to a ligand-to-metal charge transfer $\left(\mathrm{O}^{2-}-\mathrm{W}^{6+}\right)$ [52]. After the introduction of the tungsten species into the silica matrix, two ligand-to-metal charge transfer bands were observed near 202 and $267 \mathrm{~nm}\left(\mathrm{O}_{2 s}-\mathrm{W}_{5 d}-\mathrm{O}_{2 p}\right)$. The absorption onset of the $\mathrm{W}-\mathrm{SiO}_{2}-y$ materials was shifted to a lower wavelength by approximately $100 \mathrm{~nm}$ when compared with bulk $\mathrm{WO}_{3}$, which indicated that the tungsten species were incorporated into the silica matrix [53].

To examine the structure of the tungsten species that were incorporated into the hybrid materials, Raman scattering spectroscopy was used (Fig. 3). Bulk $\mathrm{WO}_{3}$ (Fig. 3(1)) exhibited a series of characteristic peaks in the regions $1000-600 \mathrm{~cm}^{-1}$ and 600-150 $\mathrm{cm}^{-1}$ that were assigned to $\mathrm{W}-0$ stretching and bending vibrations, respectively [54]. These bands were also observed in the $\mathrm{W}_{-} \mathrm{SiO}_{2}-y$ materials (Fig. 3(2)-(4)) and as the

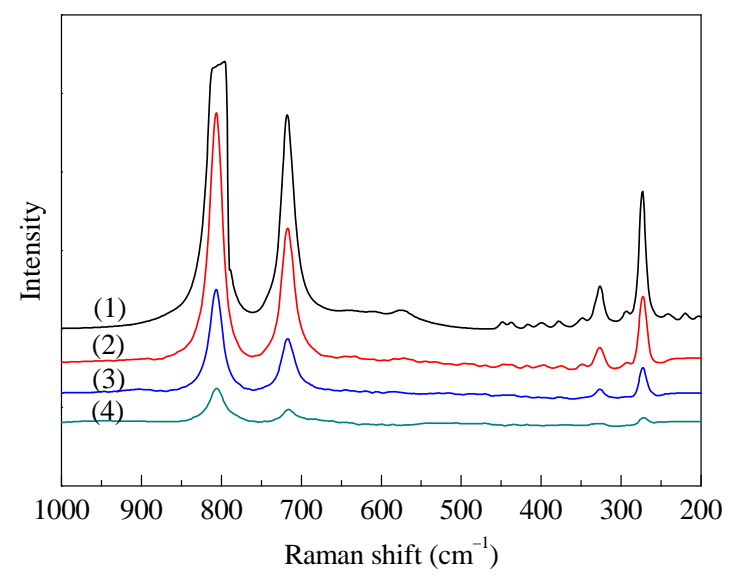

Fig. 3. Raman spectra of (1) $\mathrm{WO}_{3},(2) \mathrm{W}-\mathrm{SiO}_{2}-10,(3) \mathrm{W}-\mathrm{SiO}_{2}-20$, and (4) $\mathrm{W}-\mathrm{SiO}_{2}-40$. 
tungsten content increased, the bands became more intense and well defined. These results indicated that the tungsten species in the hybrid materials were tungsten oxide.

XRD pattern was performed to analyze the composition and phase structure of the $\mathrm{W}-\mathrm{SiO}_{2}-\mathrm{y}$ materials (Fig. 4). Small angle XRD patterns of the samples exhibited a broad diffraction peak that was located at approximately $2 \theta=2.2^{\circ}$, which is a feature of mesoporous materials (Fig. 4(a)). However, the wide-angle XRD patterns exhibited a broad peak that was consistent with amorphous silica walls (Fig. 4(b)). The diffraction peaks of crystalline $\mathrm{WO}_{3}$ were not obvious, even in the $\mathrm{W}-\mathrm{SiO}_{2}$ sample that had a relatively high tungsten content $(\mathrm{Si} / \mathrm{W}=10)$, which indicated that the tungsten species were effectively dispersed throughout the silica matrix.

Nitrogen adsorption-desorption isotherms and the BJH pore-size distribution curves are shown in Fig. 5. The nitrogen adsorption-desorption isotherms of all samples were assigned according to the IUPAC classification as Type IV, which is characteristic of a mesostructure in $\mathrm{W}-\mathrm{SiO}_{2}$ materials (Fig. 5(a)). Typical unimodal pore-size distribution curves with pore diameters that ranged between 2 and $5 \mathrm{~nm}$ indicated the uniform mesoporosity of the hybrid materials (Fig. 5(b)). The textural properties of the samples are listed in Table 1 . The $\mathrm{W}-\mathrm{SiO}_{2}-40$ sample had a surface area of $743 \mathrm{~m}^{2} / \mathrm{g}$, a pore volume of 0.50 $\mathrm{cm}^{3} / \mathrm{g}$, and a pore size of $3.20 \mathrm{~nm}$. As the tungsten content within the samples increased, the BET surface area, pore volume and pore size decreased. This effect has been reported to be caused by the anchoring of tungsten species in the pore walls [55], which was confirmed by the results of the low-angle $\mathrm{XRD}$ analysis.

TEM was used to investigate the structural features of the representative sample. TEM images of $\mathrm{W}-\mathrm{SiO}_{2}-20$ exhibited numerous interconnected worm-like mesoporous structures with a disordered arrangement (Fig. 6). The pore diameters determined from the TEM images ranged from 2 to $4 \mathrm{~nm}$, which was close to the average pore size determined from the nitrogen desorption isotherm $(2.9 \mathrm{~nm})$. The TEM images also confirmed the low-angle XRD results and textural properties listed in Table 1.

\subsection{Catalytic performance of the samples}

The removal of DBT from the sample oil by the $\mathrm{W}-\mathrm{SiO}_{2}-y$ materials under identical conditions is shown in Fig. 7. Both $\mathrm{W}-\mathrm{SiO}_{2}-10$ and $\mathrm{W}-\mathrm{SiO}_{2}-20$ achieved deep desulfurization within 40 min. Importantly, $\mathrm{W}-\mathrm{SiO}_{2}-20$ catalyzed the complete removal of DBT in $30 \mathrm{~min}$, which was higher than either $\mathrm{W}-\mathrm{SiO}_{2}-10$ or $\mathrm{W}-\mathrm{SiO}_{2}-40$ (97.7\% and 69.4\%, respectively). This may have
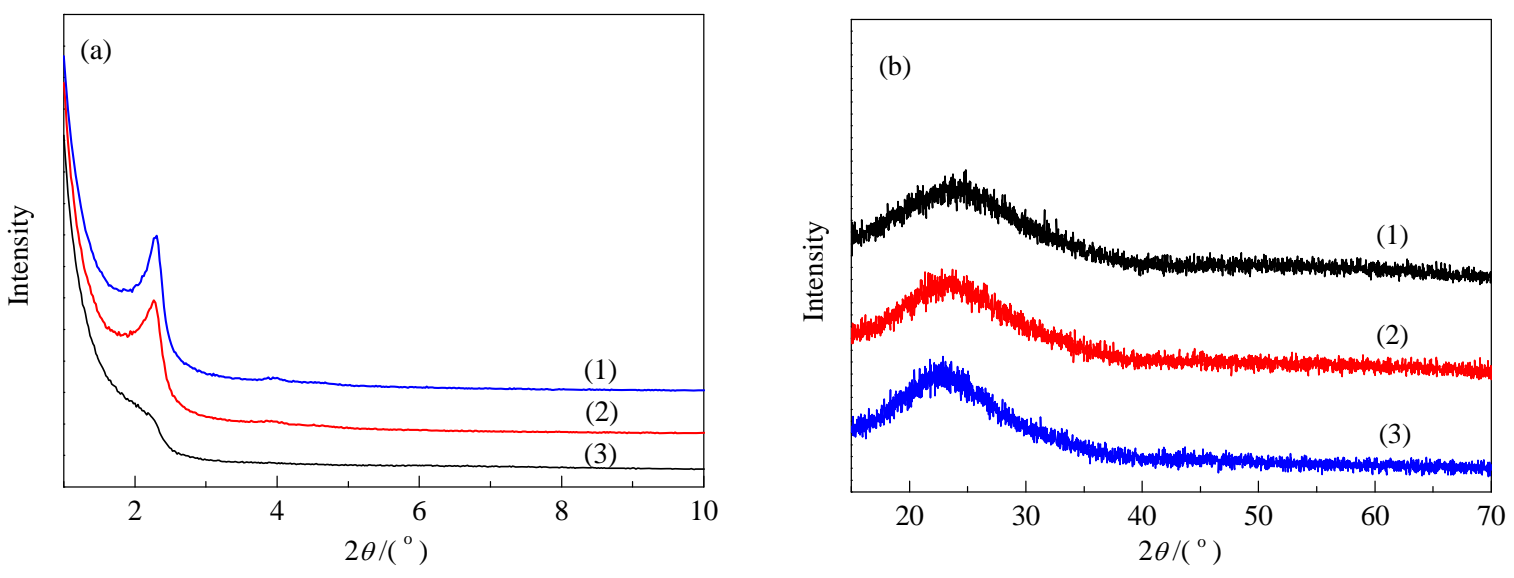

Fig. 4. (a) Low-angle and (b) wide-angle XRD patterns of (1) $\mathrm{W}-\mathrm{SiO}_{2}-10$, (2) $\mathrm{W}-\mathrm{SiO}_{2}-20$, and (3) $\mathrm{W}-\mathrm{SiO}_{2}-40$.
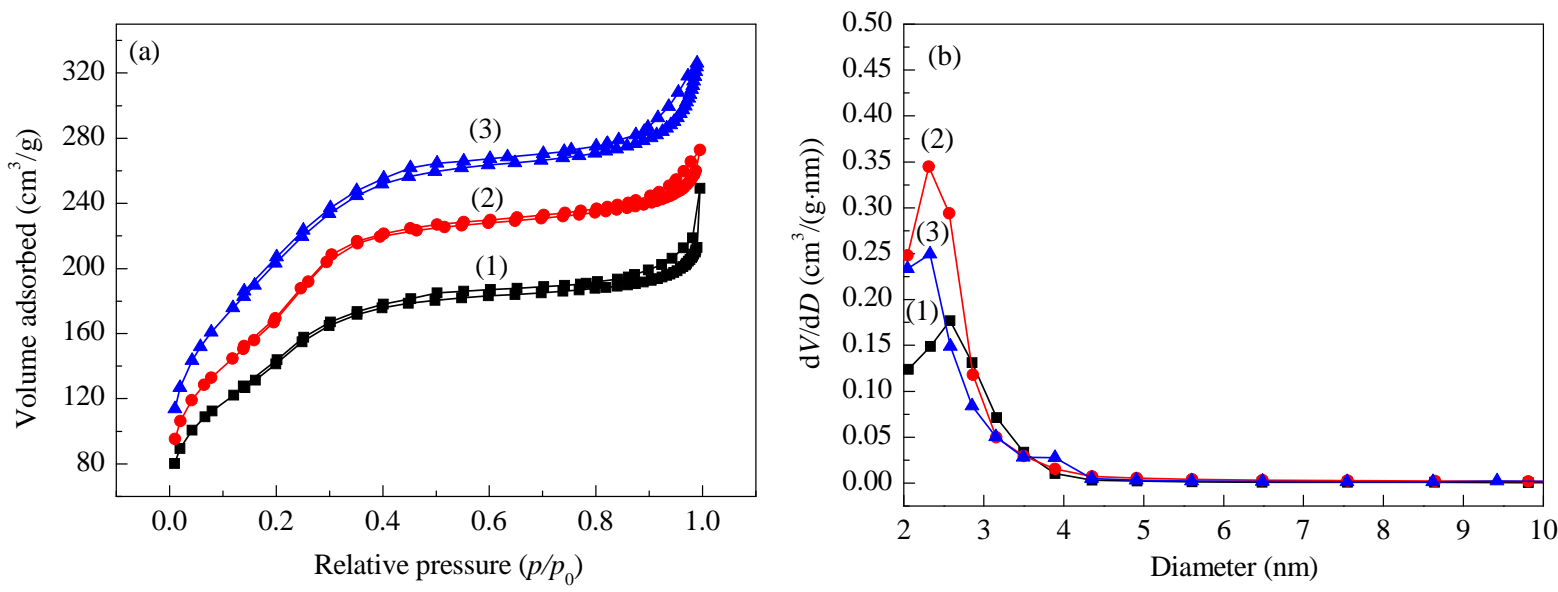

Fig. 5. (a) Nitrogen adsorption-desorption isotherms and (b) pore-size distribution of (1) W- $\mathrm{SiO}_{2}-10,(2) \mathrm{W}-\mathrm{SiO}_{2}-20$, and (3) W-SiO $2-40$. 


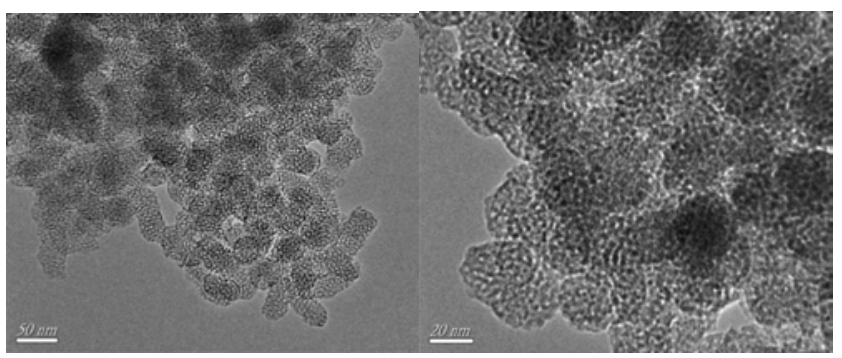

Fig. 6. TEM images of the $\mathrm{W}-\mathrm{SiO}_{2}-20$ sample.

Table 1

Textural properties of $\mathrm{W}-\mathrm{SiO}_{2}-10, \mathrm{~W}-\mathrm{SiO}_{2}-20$, and $\mathrm{W}-\mathrm{SiO}_{2}-40$.

\begin{tabular}{lcccc}
\hline Sample & $\begin{array}{c}\text { W/Si molar } \\
\text { ratio }\end{array}$ & $\begin{array}{c}\text { BET area } \\
\left(\mathrm{m}^{2} / \mathrm{g}\right)\end{array}$ & $\begin{array}{c}\text { Pore volume } \\
\left(\mathrm{cm}^{3} / \mathrm{g}\right)\end{array}$ & $\begin{array}{c}\text { Pore size } \\
(\mathrm{nm})\end{array}$ \\
\hline $\mathrm{W}-\mathrm{SiO}_{2}-10$ & $1: 46$ & 513 & 0.37 & 2.91 \\
$\mathrm{~W}^{-\mathrm{SiO}_{2}-20}$ & $1: 88$ & 612 & 0.42 & 2.98 \\
$\mathrm{~W}-\mathrm{SiO}_{2}-40$ & $1: 107$ & 743 & 0.50 & 3.20 \\
\hline
\end{tabular}

${ }^{*}$ Measured by ICP.

been because $\mathrm{W}-\mathrm{SiO}_{2}-20$ possessed a larger BET surface area and pore volume compared with $\mathrm{W}-\mathrm{SiO}_{2}-10$, and more active sites (tungsten species) compared with $\mathrm{W}-\mathrm{SiO}_{2}-40$. The adsorption desulfurization of DBT was also investigated without the presence of $\mathrm{H}_{2} \mathrm{O}_{2}$ (catalyst $=0.01 \mathrm{~g}, T=60{ }^{\circ} \mathrm{C}, t=40 \mathrm{~min}$ ). This experiment yielded adsorption desulfurization values of $6.9 \%$, $5.6 \%$, and $4.7 \%$, which corresponded to calculated adsorptive capacities of $17.2,14.0$, and $11.7 \mathrm{mg} / \mathrm{g}$ for $\mathrm{W}-\mathrm{SiO}_{2}-40$, $\mathrm{W}-\mathrm{SiO}_{2}-20$, and $\mathrm{W}-\mathrm{SiO}_{2}-10$, respectively.

The identity of a sulfur-containing compound can influence the ability of a catalyst to remove sulfur. The effectiveness of $\mathrm{W}$-SiO2-20 for the removal of a series of organosulfur compounds was studied. In addition to DBT, the compounds BT, 4,6-DMDBT and DT were examined (Fig. 8). The removal of sulfur reached equilibrium after approximately $30 \mathrm{~min}$ except for 4,6-DMDBT, which took $20 \mathrm{~min}$. The levels of sulfur removal from the oil after $20 \mathrm{~min}$ for BT, DBT, DT and 4,6-DMDBT were $84.4 \%, 90.4 \%, 75.0 \%$ and $100.0 \%$, respectively. Thus, the ability of $\mathrm{W}-\mathrm{SiO}_{2}-20$ to remove sulfur decreased in the order 4,6-DMDBT > DBT > BT > DT. This decrease in ability to remove sulfur corresponded to the decrease in sulfur electron density of the aromatic compounds (4,6-DMDBT (5.760) > DBT (5.758)

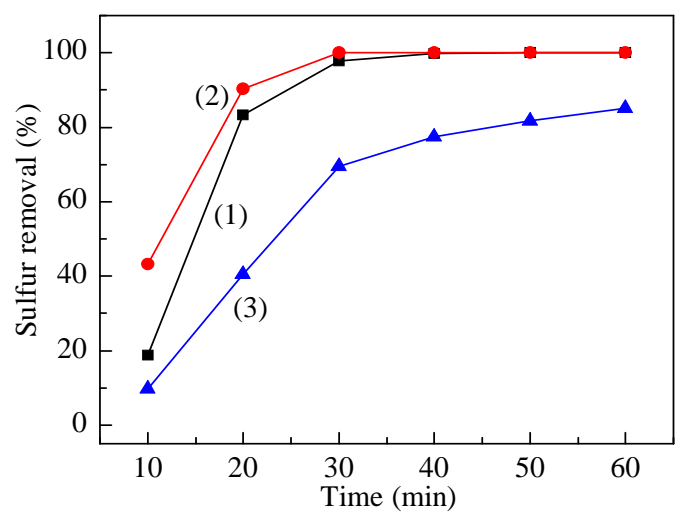

Fig. 7. Removal of DBT from the sample oil using (1) $\mathrm{W}-\mathrm{SiO}_{2}-10$, (2) $\mathrm{W}-\mathrm{SiO}_{2}-20$, and (3) $\mathrm{W}-\mathrm{SiO}_{2}-40$. Reaction conditions: catalyst $=0.01 \mathrm{~g}$, $\mathrm{O} / \mathrm{S}=2.5, T=60^{\circ} \mathrm{C}$.

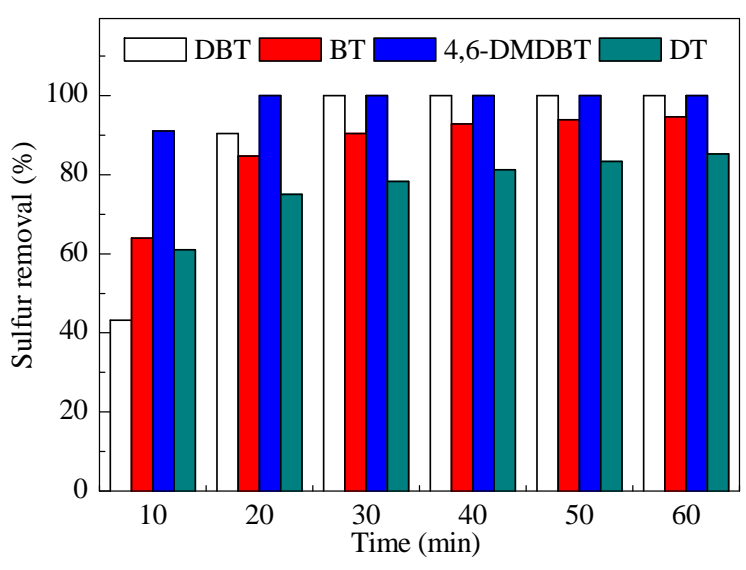

Fig. 8. Removal of various sulfur-containing compounds during desulfurization. Reaction conditions: catalyst $\left(\mathrm{W}-\mathrm{SiO}_{2}-20\right)=0.01 \mathrm{~g}, 0 / \mathrm{S}=2.5$, $T=60^{\circ} \mathrm{C}$.

> BT (5.739)] [56]. However, the sulfur removal of DT was the lowest, which was attributed to the strong steric hindrance of the long carbon chains.

The ability of the catalyst to be recycled was investigated. After the first reaction, the upper oil phase was separated by decanting from the reactor. The remaining catalyst within the reactor was dried at $60{ }^{\circ} \mathrm{C}$ overnight, and then fresh $\mathrm{H}_{2} \mathrm{O}_{2}$ and model oil were added to the reactor for the next cycle. The ability of the catalyst to remove sulfur from the reaction system was able to reach $90.3 \%$ after recycling seven times, as shown in Fig. 9.

The oxidation products of DBT were determined using GC-MS analysis after reaction (Fig. 10). The upper oil layer was decanted, and the used catalyst was extracted using carbon tetrachloride for the GC-MS analysis. A single, intense peak at $3.4 \mathrm{~min}$ was ascribed to $n$-tetradecane, which indicated that DBT was completely removed from the oil phase (Fig. 10(a)). The GC trace for the extracted catalyst only exhibited an obvious peak at $9.8 \mathrm{~min}$, which corresponded to $\mathrm{DBTO}_{2}$ (Fig. 10(b), inset). The fact that a peak for DBT was not detected demonstrated that it was entirely oxidized to $\mathrm{DBTO}_{2}$ in the desulfurization process.

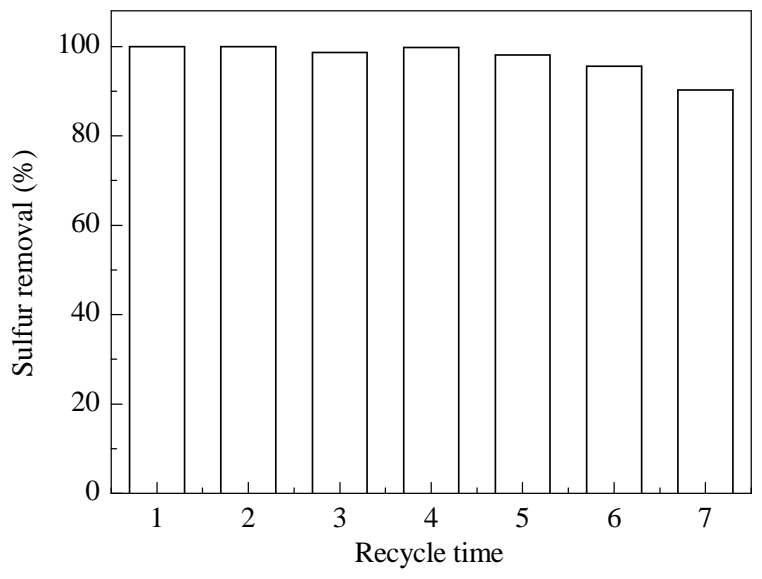

Fig. 9. Recycling ability of the catalyst. Reaction conditions: catalyst $\left(\mathrm{W}-\mathrm{SiO}_{2}-20\right)=0.01 \mathrm{~g}, 0 / \mathrm{S}=2.5, T=60^{\circ} \mathrm{C}, t=40 \mathrm{~min}$. 

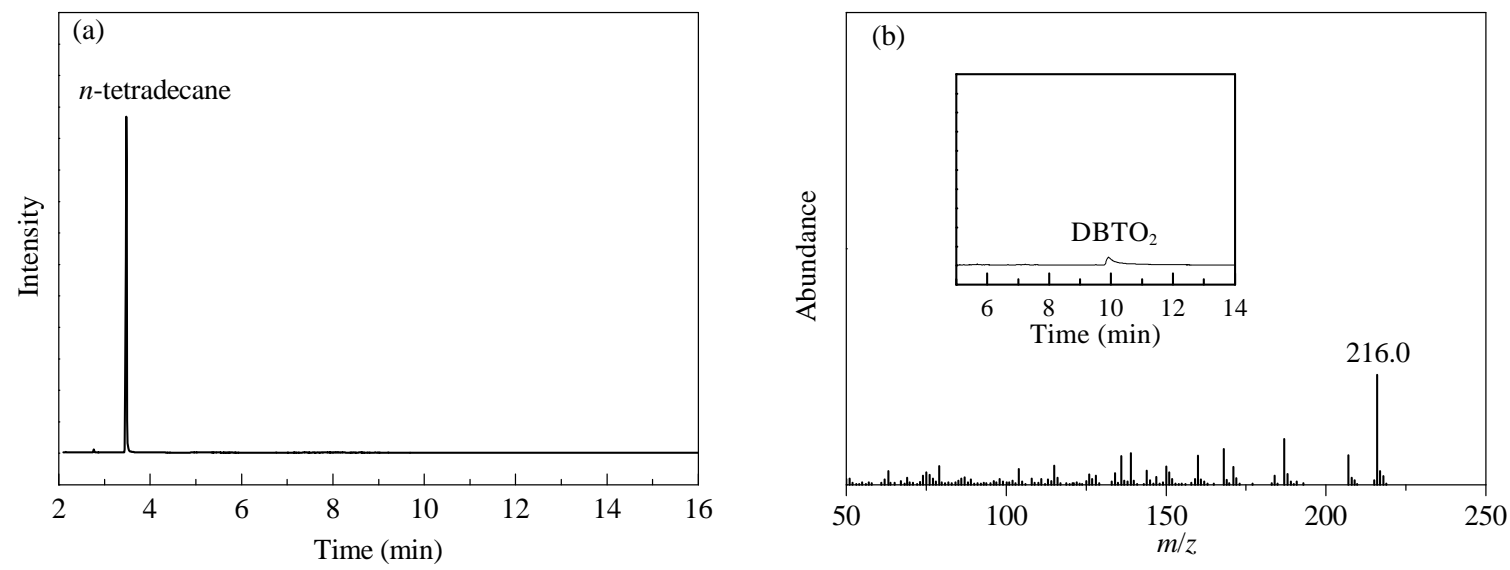

Fig. 10. (a) GC analysis of the upper oil after reaction and (b) GC-MS analysis of sulfur compounds in the catalyst after reaction.

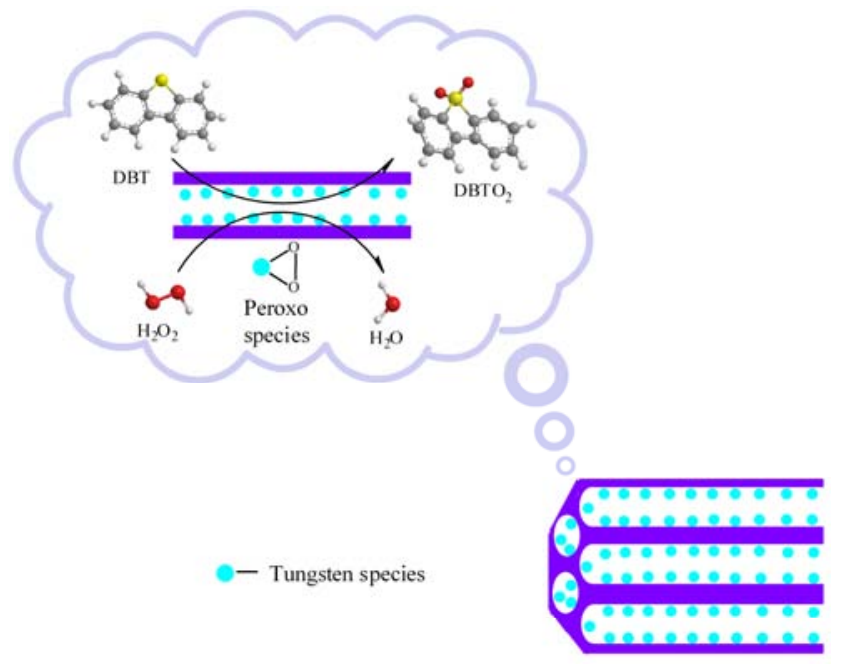

Fig. 11. Oxidative desulfurization procedure of DBT in the presence of mesoporous $\mathrm{W}-\mathrm{SiO}_{2}$ as catalyst.

\subsection{Proposed mechanism of the reaction}

A potential mechanism for the desulfurization process using the $\mathrm{W}-\mathrm{SiO}_{2}$ catalysts is shown in Fig. 11. Initially, DBT is absorbed by $\mathrm{W}-\mathrm{SiO}_{2}$ and is oxidized by the active peroxo species, which are formed by the reaction of the tungsten species and $\mathrm{H}_{2} \mathrm{O}_{2}$. The sulfone species that is subsequently formed $\left(\mathrm{DBTO}_{2}\right)$ can also be absorbed by $\mathrm{W}-\mathrm{SiO}_{2}$. As the reaction proceeds, the peroxo species transformed to tungsten species, which could continually combine with $\mathrm{H}_{2} \mathrm{O}_{2}$ [57].

\section{Conclusions}

In summary, a series of mesoporous materials $\left(\mathrm{W}-\mathrm{SiO}_{2}\right)$ were synthesized using a one-pot method from a POM-based IL. These materials contained tungsten species that were effectively dispersed throughout the silica matrix. The hybrid catalysts exhibited excellent activity for the removal of a number of different sulfur-containing compounds from a model oil, with low amounts of co-oxidant $(0 / \mathrm{S}$ molar ratio $=2.5)$ in approximately $40 \mathrm{~min}$. This process did not require the addition of organic solvents as an extractant. The ability of the catalysts to remove sulfur compounds decreased in the order: 4,6-DMDBT $>$ DBT > BT > DT. Importantly, the catalyst could be recycled up to seven times without any significant decrease in activity.

\section{Acknowledgments}

The authors wish to acknowledge the financial support provided by Advanced Talents of Jiangsu University (13JDG080), Postdoctoral Foundation of China (2014M551516), and A Project Funded by the Priority Academic Program Development of Jiangsu Higher Education Institutions (PAPD).

\section{References}

[1] J. Eßer, P. Wasserscheid, A. Jess, Green Chem., 2004, 6, 316-322.

[2] H. W. Zheng, Z. Sun, X. L. Chen, Q. Zhao, X. H. Wang, Z. J. Jiang, Appl. Catal. A, 2013, 467, 26-32.

[3] I. V. Babich, J. A. Moulijn, Fuel, 2003, 82, 607-631.

[4] H. P. Li, W. S. Zhu, S. W. Zhu, J. X. Xia, Y. H. Chang, W. Jiang, M. Zhang, Y. W. Zhou, H. M. Li, AIChE J., 2016, 62, 2087-2100.

[5] W. S. Zhu, B. L. Dai, P. W. Wu, Y. H. Chao, J. Xiong, S. H. Xun, H. P. Li, H. M. Li, ACS Sustain. Chem. Eng., 2015, 3, 186-194.

[6] L. F. Ramirez-Verduzco, E. Torres-Garcia, R. Gomez-Quintana, V. Gonzalez-Pena, F. Murrieta-Guevara, Catal. Today, 2004, 98, 289-294.

[7] C. S. Song, X. L. Ma, Appl. Catal. B, 2003, 41, 207-238.

[8] M. Zhang, W. S. Zhu, H. M. Li, S. H. Xun, W. J. Ding, J. J. Liu, Z. Zhao, Q. Wang, Chem. Eng. J., 2014, 243, 386-393.

[9] N. F. Nejad, E. Shams, M. K. Amini, J. C. Bennett, Fuel Process. Technol., 2013, 106, 376-384.

[10] J. Xiao, L. M. Wu, Y. Wu, B. Liu, L. Dai, Z. Li, Q. B. Xia, H. X. Xi, Appl. Energy, 2014, 113, 78-85.

[11] A. Bosmann, L. Datsevich, A. Jess, A. Lauter, C. Schmitz, P. Wasserscheid, Chem. Commun., 2001, 2494-2495.

[12] N. H. Ko, J. S. Lee, E. S. Huh, H. Lee, K. D. Jung, H. S. Kim, M. Cheong, Energy Fuels, 2008, 22, 1687-1690.

[13] C. Asumana, G. R. Yu, X. Li, J. J. Zhao, G. Liu, X. C. Chen, Green Chem., 2010, 12, 2030-2037.

[14] F. T. Li, Y. Liu, Z. M. Sun, L. J. Chen, D. S. Zhao, R. H. Liu, C. G. Kou, Energy Fuels, 2010, 24, 4285-4289.

[15] J. M. Kwon, J. H. Moon, Y. S. Bae, D. G. Lee, H. C. Sohn, C. H. Lee, 


\title{
Graphical Abstract
}

Chin. J. Catal., 2016, 37: 971-978 doi: 10.1016/S1872-2067(15)61103-2

Fabrication and characterization of tungsten-containing mesoporous silica for heterogeneous oxidative desulfurization

Ming Zhang, Wenshuai Zhu*, Hongping Li, Suhang Xun, Meng Li, Yanan Li, Yanchen Wei, Huaming Li*

Jiangsu University

In the desulfurization process, the organic sulfur compounds were firstly absorbed by the mesoporous material and then oxidized into the corresponding sulfones by the active peroxo species, which were formed by reaction of tungsten species and $\mathrm{H}_{2} \mathrm{O}_{2}$.

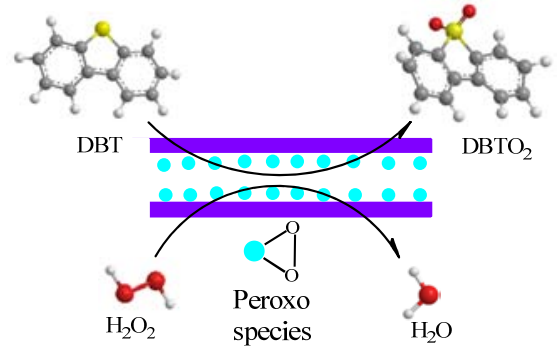

X. P. Sun, P. L. Ying, C. R. Han, Chem. Eur. J., 2004, 10, 2277-2280.

[37] H. Y. Lu, J. B. Gao, Z. X. Jiang, Y. X. Yang, B. Song, C. Li, Chem. Commun., 2007, 150-152.

[38] G. J. Wang, N. Y. Yu, L. Peng, R. Tan, H. H. Zhao, D. H. Yin, H. Y. Qiu, Z. H. Fu, D. L. Yin, Catal. Lett., 2008, 123, 252-258.

[39] P. P. Zhao, M. J. Zhang, Y. J. Wu, J. Wang, Ind. Eng. Chem. Res., 2012, 51, 6641-6647.

[40] E. Rafiee, S. Eavani, J. Mol. Catal. A, 2013, 380, 18-27.

[41] S. Ribeiro, A. D. S. Barbosa, A. C. Gomes, M. Pillinger, I. S. Gonçalves, L. Cunha-Silva, S. S. Balula, Fuel Process. Technol., 2013, 116, 350-357.

[42] X. J. He, N. Zhao, J. S. Qiu, N. Xiao, M. X. Yu, C. Yu, X. Y. Zhang, M. D. Zheng, J. Mater. Chem. A, 2013, 1, 9440-9448.

[43] J. X. Wu, Y. L. Gao, W. Zhang, Y. Y. Tan, A. M. Tang, Y. Men, B. Tang, Appl. Organomet. Chem., 2015, 29, 96-100.

[44] D. Xie, Q. H. He, Y. Y. Su, T. W. Wang, R. F. Xu, B. X. Hu, Chin. J. Catal., 2015, 36, 1205-1213.

[45] Z. E. A. Abdalla, B. S. Li, Chem. Eng. J., 2012, 200-202, 113-121.

[46] J. Zhang, A. J. Wang, X. Li, X. H. Ma, J. Catal., 2011, 279, 269-275.

[47] T. Rajkumar, G. R. Rao, J. Chem. Sci., 2008, 120, 587-594.

[48] D. Rath, S. Rana, K. M. Parida, Ind. Eng. Chem. Res., 2010, 49, 8942-8948.

[49] R. Nava, A. Infantes-Molina, P. Castano, R. Guil-Lopez, B. Pawelec, Fuel, 2011, 90, 2726-2737.

[50] B. Pawelec, S. Damyanova, R. Mariscal, J. L. G. Fierro, I. Sobrados, J. Sanz, L. Petrov, J. Catal., 2004, 223, 86-97.

[51] H. Chen, W. L. Dai, J. F. Deng, K. N. Fan, Catal. Lett., 2002, 81, 131-136.

[52] X. L. Yang, W. L. Dai, R. H. Gao, K. N. Fan, J. Catal., 2007, 249, 278-288.

[53] R. H. Gao, X. L. Yang, W. L. Dai, Y. Y. Le, H. X. Li, K. N. Fan, J. Catal., 2008, 256, 259-267.

[54] D. E. Diaz-Droguett, R. El Far, V. M. Fuenzalida, A. L. Cabrera, Mater. Chem. Phys., 2012, 134, 631-638.

[55] Z. E. A. Abdalla, B. S. Li, A. Tufail, Colloids Surf. A, 2009, 341, 86-92.

[56] D. Xu, W. S. Zhu, H. M. Li, J. T. Zhang, F. Zou, H. Shi, Y. S. Yan, Energy Fuels, 2009, 23, 5929-5933.

[57] W. S. Zhu, H. M. Li, X. Jiang, Y. S. Yan, J. D. Lu, L. N. He, J. X. Xia, Green Chem., 2008, 10, 641-646.

\section{功能化含铇介孔硅材料的直接合成表征及其在多相氧化脱硫中的应用}

\author{
张 铭 ${ }^{\mathrm{a}}$ ，朱文帅 ${ }^{\mathrm{b}}{ }^{*}$ ，李宏平 ${ }^{\mathrm{b}}$, 荀苏杭 ${ }^{\mathrm{b}}$ ，李 猛 $^{\mathrm{b}}$ ，李亚男 ${ }^{\mathrm{b}}$ ，魏延臣 ${ }^{\mathrm{b}}$ ，李华明 ${ }^{\mathrm{a}, \mathrm{b}, \#}$ \\ a江苏大学能源研究院, 江苏镇江 212013 \\ b江苏大学化学化工学院, 江苏镇江212013
}


摘要: 温和条件下, 燃油深度脱硫一直是非常重要的研究课题. 目前, 加氢脱硫 (HDS) 是石油工业上广泛采用的脱硫技术, 它能够有效脱除燃油中的硫醚、硫醇和等无机硫化物, 但对于芳香族硫化物 (如二苯并噻吩、4,6-二甲基二苯并噻吩等), 则 效果较差. 对于上述有机硫化物的深度脱除, 现有的加氢脱硫技术需要更为苛刻的反应条件, 如高温、高压、高活性贵金 属催化剂等, 这势必导致燃油成本的大幅上升. 因此, 世界各国科学家都加强了高效非加氢脱硫方法的研究, 主要包括氧 化脱硫法、吸附脱硫法、萃取脱硫法和生物脱硫法等, 其中氧化脱硫法是一种公认的具有应用前景的高效脱硫技术, 该技 术只需在常温常压下进行, 可将含硫化合物氧化成其相应的砜类物质后, 再用溶剂萃取法或吸附法除去. 氧化脱硫反应中 所涉及氧化剂有过氧化氢、有机过氧化物和氧气等. 在这些氧化剂中, 过氧化氢由于其活性高, 在氧化反应后的副产物只有 水, 而被广泛研究.

离子液体作为一种低温熔融盐, 因其独特的理化性质, 如无蒸气压、低毒性、良好的溶解性以及结构可调等, 受到了广 泛的关注. 其中, 功能化多酸基离子液体不仅具备离子液体的特点, 还具备多金属氧酸盐的优势, 已被用于燃油的均相氧 化脱硫过程中. 但是, 此过程中离子液体往往用量较大, 催化剂难于回收和循环利用, 氧化剂用量较大, 阻碍其在工业中的 应用. 为了克服上述缺点, 本课题组以多酸基离子液体 $\left[\mathrm{C}_{16} \mathrm{mim}_{3} \mathrm{PW}_{12} \mathrm{O}_{40}\right.$ 和正硅酸四乙酯为原料通过溶胶-凝胶法直接合 成了一系列含铇功能化介孔复合材料 $\mathrm{W}-\mathrm{SiO}_{2}$, 其中咪唑型阳离子作为介孔模板剂, 而多酸阴离子作为金属源. 采用 XRD, IR, Raman, BET, DRS, TEM 等测试手段对所合成的材料进行了表征. 结果表明, 铇活性物种是以氧化铇的形式存在, 并 且能够均匀地分散在载体二氧化硅上, 所合成的材料比表面积为 $513-743 \mathrm{~m}^{2} / \mathrm{g}$, 孔体积为 $0.37-0.50 \mathrm{~cm}^{3} / \mathrm{g}$, 孔径为 2.91-3.20 nm. 将所合成的材料 W- $\mathrm{SiO}_{2}-20$ 应用于燃油氧化脱硫反应 (过程中无需有机溶剂), 结果表明, 所合成的复合材料 既能作为吸附剂来吸附有机硫化物, 又能作为催化剂来活化过氧化氢以氧化有机硫化物. 在最优条件 (反应温度 $60^{\circ} \mathrm{C}$, $\mathrm{O} / \mathrm{S}$ 摩尔比为 2.5 , 反应时间 $40 \mathrm{~min}$ ) 下, 二苯并噻吩脱除率可 $100 \%$, 而且反应体系易于循环使用, 7 次循环后脱硫率无明 显降低. 此外, 还考察了复合材料在相同条件下对于不同硫化物的脱除效果, 结果表明, 反应活性顺序为 4,6-DMDBT > $\mathrm{DBT}>\mathrm{BT}>\mathrm{DT}$.

关键词: 多相氧化脱硫; 氧化铇; 介孔二氧化硅; 一锅法合成; 有机硫化物

收稿日期: 2016-01-29. 接受日期: 2016-04-07. 出版日期: 2016-06-05.

*通讯联系人. 电话: (0511)88791800; 传真: (0511)88791708; 电子信箱: zhuws@ujs.edu.cn

\#通讯联系人. 电话: (0511)88791800; 传真: (0511)88791708; 电子信箱: lhm@ujs.edu.cn

基金来源：国家自然科学基金 (21276117, 21376111, 21406092).

本文的英文电子版由Elsevier出版社在ScienceDirect上出版(http://www.sciencedirect.com/science/journal/18722067). 